\title{
Disturbance of Native Americans as Reflected in Selected Folkloric Poems of Luci Tapahonso, Joy Harjo and Simon Ortiz
}

\author{
Widad Allawi Saddam (Corresponding author) \\ Faculty of Modern Languages and Commination, University Putra Malaysia, Malaysia \\ E-mail: wedad.saddam@yahoo.com \\ Wan Roselezam Wan Yahya \\ Faculty of Modern Languages and Commination, University Putra Malaysia, Malaysia \\ Hardev Kaur A/P Jujar Singh, \\ Faculty of Modern Languages and Commination, University Putra Malaysia, Malaysia \\ Manimangai Mani \\ Faculty of Modern Languages and Commination, University Putra Malaysia, Malaysia
}

Received: 25-08-2016

Published: 10-12-2016
Accepted: 21-10-2016

doi:10.7575/aiac.ijalel.v.5n.7p.248
Advance Access Published: November 2016

URL: http://dx.doi.org/10.7575/aiac.ijalel.v.5n.7p.248

\begin{abstract}
As a result of colonialization and assimilation, the natives were disturbed between past and present. Adopting the colonizer culture, style of life, language and changing home place come together in the mind of Native American people and lead them to be confused; they intermingle between past and present. They want to be themselves but the colonizer wants them to be the others. This feeling of disturbance affected Native American people, especially the chosen poets for this study. This paper shows how Native American people reflect their disturbance toward the colonization in their folkloric poetry. It explains how each element of folklore represents their disturbance towards the colonizer's dominant culture. This paper will be done under postcolonial framework utilizing Frantz Fanon's second views about the natives. Disturbance follows assimilation and they together forced Native Americans to present fighting literature which shows the third phase of Fanon.
\end{abstract}

Keywords: assimilation, disturbance, Native Americans, Frantz Fanon, folklore

\section{Introduction}

Disturbance, or the second stage of Fanon's views concerning the Natives, occurs just before the start of the anticolonial battle, that is, just before the emergence of a fully conscious and concerted decolonizing force. In this stage, we find the native is disturbed; he decides to remember what he is. He tries to remember the old legends and will try to reinterpret them in the light of a borrowed culture. He remains, however, unable to fully participate in or reflect the lived experience of his people because he has only a superficial relation with them.

Native American people show their disturbance because of the harsh circumstances caused by assimilation, like displacement and hybridity. The oppression and the suffering of Native American through the practices of the colonization lead them to be confused and disturbed between their glorious past and their difficult present which is full of discrimination and disruption.

\section{Analysis}

Tapahonso reflects on her disturbance in her poem "Starlore." The first stanza of the poem "Starlore" by Luci Tapahonso illustrates the split-up of past and present, and appears to depict a mixture of the two. The Natives drive their cars to attend a ceremony and park them by the traditional Native houses called hooghan; they are apparently living in both present and past at the same time. This stanza finishes by voicing that the people wait for "he... who knows the precise songs, the long, rhythmic prayers that will restore the world for us" (Tapahonso 2.16-19). It appears that this character could simultaneously be interpreted as a number of figures. A way of interpretation, definitely, is that he is a kind of medicine man. A medicine man in Navajo culture was someone who was familiar with the meanings of the stars, and has probably the power to heal and restore the world. Medicine man is a famous character in Native American folklore. He is such an important person and his position is like a leader. By referring to this person Tapahonso reflects her need to him to relief her from her feeling of disturbance.

A round and cone-shaped structure for traditional dwelling enclosed the lives of the Navajo people, and became the homes to their culture. These homes for Navajo families were known as hogans, or "hooghans"(15). The speaker of Tapahanso's poem, "Starlore" experiences an ethereal life while being surrounded and connected to her family and community and her environment and nature. This traditional life enriches the native person with spiritual awareness of 
their existence. For example, they build their doors facing the rising sun from the east to welcome each day with good luck which helps connecting their physical life to their spiritual life. This entrance signals the place that happiness and joy come indie the Navajo housing. The narrator in this poem tells of her and her family's entrance into the hooghan "clockwise" and then making room for themselves on the "smooth, cool ground" (15). This "clockwise" movement highlights the spiritual ties of the Native people with the elements of this world.

However, this spiritual connection has its own limits. It has effect only inside this close knit inside the hooghan. Tapahonso does mention that the members of the family feel the sense of fear inside them when they go outside this familiar world into the outside. She says, "Families could split into hardened circles over one sentence uttered in anger" and "parents would not know all they (their children) endured" (15). Moreover, the poem is concluded by admitting that "we address our fears in ways that have never changed"(15). The narrator mentions her family's lack of understanding about each others with regret by emphasizing that the emotions and connection tie the members inside their traditional houses and environment but outside of it, the hardships and challenges of the world pull them away from each other and this is an awareness that comes late.

"Starlore" talks of a time of transition and how families are trapped in a culture of past and present families have split. While there used to be a time that community was very important to the tribe people, now it is replaced with standalone families which suffer from strife and misunderstanding between their own members.

"The Wrap is even" illustrates Luci Tapahonso's great craving to the past through demonstrating the image of her own father and her certain attitude to nature. The repeated line "Today I began a new", indicates the poet's internal shift which begins with the 'grey,' 'moisty,' 'damp,' 'cold' early morning she describes. The following stanza transfers the reader to the present situation which is, in fact, the past. In 'This afternoon'; there are related things to her native culture like 'phone call, class preparations, since she is decisive to begin anew on that day. Addressing the 'loom,' she mentions that it 'has not rained here for months." She makes a tactful connection between her mother's weaknesses of eyesight and the lack of 'rain.' The repetition of the word 'today' denotes something changeable. In order to remember the past, she decides to do a 'new' rug. She remembers the old wonderfully done rug her aged grandmother made for her deceased father. By "a new for my mother's memories" the poet signifies the permanency of her culturally inherited traditions, folklore and customs. The mother and grandmother stand for their own traditions and history. In order to make connection between the past and the present, she teaches her grandson all her customs as well as traditions, and finally, makes a new rug for him.

\section{Recalling the past}

In his novel, Nineteen Eighty-Four, George Orwell states that "He who controls the past controls the future". These lines are very significant in stating why it was important for the natives to regain control of their past and cultural history and why it can be a useful tool for resistance. The first step that Fanon suggests colonized people take in finding their own voice and identity is to reclaim their own past. That is getting in touch with who they were and how they lived before being influenced by colonizers. The European colonizing power devalued the nation's past for centuries, considering its precolonial era as a pre-civilized limbo, or even as historical void. Since the arrival of European, Children, both black and white, were taught to see history, culture and progress as the beginning. So if the colonized want to regain their past they should get rid of the colonialist ideology by which that past had been devalued (Barry, 2002, 193).

This homogenization of native culture, according to Fanon, becomes contradictory towards the past and far from the real events of the present. What it holds in the end is a non-existent core that has become stable and made permanently coherent. He also asserts that the popular efforts of the people must be related to the construction of national culture. (Zhaogue , 2011) In other words, this homogenization alienates the Native Americans from their own past and make them unfamiliar with their present actual events. This brings about a fake essence which becomes internalized by the people and consequently, deprives them of having a real national culture.

The native intellectuals, who refused imitating the colonizers' culture and mindset, began to work enthusiastically on their own cultural history. As a result, they looked back and honored their indigenous background. According to Fanon, this literature which embraces the Native intellectuals' reflection upon their own ethnical culture and history is of 'just -before-the -battle'. (Mcleod, 2000, 86). Joy Harjo argues poverty, depression, self-doubt, alcoholism and violence are troubles forced upon the Natives by colonization. The natives have experienced an endless war for one or two centuries. During these suffering times, many of them sing, express, and reminisce through the language of enemy. (Bird \& Harjo, 1997, 20)

The native's past was controlled and diminished by the white, their present and future was affected too. Sense of loss is the outcome of losing one's history and identity; Identity is who a person is in both the past and present and it also determines a person's future too. Native Americans' identity is inseparable from their lands. Therefore, when they got displaced what they really lost besides their land was a part of their culture, and the idea that they are the true dwellers of America. (Carpenter, 2004) According to Harjo, the Natives have been expatriated and vanished in their own homeland. This provides them with a vague sense of history, since they are not aware of the fact and history of how America appeared. Joshua Barnes compares the Natives and African Americans and says that in contrast with the Native Americans who seem to live in a kind of exile, Africans possess their own lands and that only one half of one percent indigenous people live there, and the tribes have their original lands. (Barnes, 2013 ) 
Simon Ortiz' observations about the fate of his race is scripted in "From Sand Creek" his cycle of poems published in 1981. Ortiz starts his preface talking about the Native American history and culture. Unfortunately, this is the same history Native American people felt foreign to sometimes. Moreover, Native American people felt they have no history. They intermingle between American history and U.S. history. Since they were alienated from history, Native American people felt that they were pushed away consciously. Ortiz believes that Native Americans were made to vanish, and the aim of his poetry is helping them retrieve their past. In "This way still we shall go on," Ortiz emphasizes the idea of looking back to the past life of the Native American life. He tells his readers that the past life was perfect and well guided, and then they should follow it to get the right way in the present life.

It is necessary to look back to the past.

How they were guided, how they lived well,

We who are living today, that is how we are to be guided by,

That is the way of living that will be correct and good for us.

Through re-imagining and remembering history in from Sand Creek, Ortiz appears as a witness to the massacre of the past which he believes continues the trend of subjugation embodied by the massacre. He also asks his readers to witness by listening to and accepting these histories. (Fast, 2000, 53). In addition to voicing the realities of indigenous people, Ortiz, probably, expresses all people's lives. He articulates struggles when confronted with oppression and genocide of colonizers which is currently relevant on a universal scale.

As a significant poet and teller of tales, an activist, and an educator, Simon Ortiz writes poetry for all native people in the world from Acoma to Pueblo. Not only does his writing reflect the future of universal literature but embraces the glow of novel orientation of history, psychology, philosophy, language studies and folklore. (Powell, 2006, 6-7)

In this long epic poem, the lyric segments are written in the style of rhythmical Indian oral tradition preceded by a prose segment in italic which separates the fact from them. In this poem, he portrays the disastrous and heart rending massacre of Cheyenne and Araphoe people who were settled trusting the president who had guaranteed their safety. They were showing their commitment to the promise through raising the American flag visible even from the far distance. However, just ten years after Longfellow's prophecy, they were betrayed by devious Colonel W. Chivington in November 29, 1864. The colonel along with his mob of Colorado volunteers looted the miserable scattered Indians who were suffering from hunger. The Epilogue of the long narration includes a fragmentary perspective of history after the encounter of two races with completely different traditional and cultural qualifications and backgrounds, Indians with their spirituality and white men with their materialism. This Epilogue is created through recalling this catastrophic slaughter of the Indian race.

Ortiz' historiography asserts that bigoted whites considered Indians as evil creatures that must be eradicated from the vision of moral and honorable Puritans. Moreover, they regarded them as uncivilized people and accordingly practiced violation against them. They justified that this violent behavior was in favor of the civilized world. (Cruz , 2013) In 1864, U.S. soldiers mascaraed women and children of Cheyenne and Arapaho in Sand Greek. In 1998, the battlefield of this genocide which was an appalling event in American history was identified as a National Historic Site in order to commemorate the innocent victims. Seventeen years earlier, Simon Ortiz also paid homage to these victims in his own fashion.

According to Ortiz in from Sand Creek, if Natives and non-Native Americans want to heal the wounds of the past, they first have to assent that despite its acrimony they have the same history. The beginning of Ortiz's first poem appropriately articulates a testimony of America's violent past: "This America / has been a burden / of steel and mad / death" (1-4). By using the word "mad death" the poet tactfully rejects President Roosevelt's famous perception that whatever America has done has been necessary and just. He declared that it was worthy to get together in order to demonstrate that Americans do not forget what their Western pioneers had done in the past (Cruz, 2013). The episodes include randomly chosen snap-shots that expose the main spots in the encroachment of the white people to the heart of the Native people's land. They also represent the principles that would fashion the future ideology of white man as well as their greediness for power and land which stimulated their activities.

In his poem, "Hunger in New York City," Simon Ortiz declares his responsibility to his culture as well as his deep nostalgic sense of connection to "mother earth" and lands of his ancestors. The poem's simple title can easily create misinterpretation, since a reader may visualize images of hungry homeless people in New York City who are wandering or queuing for food. Although this assumption is related to the title of the poem, Ortiz shifts the concept of hunger to something considerably more profound. In the beginning of the poem, Ortiz talks about the hunger which originally comes "from somewhere out of your muscles, or concrete or the land, or the wind pushing you." Hunger may be related not just to food but to many things that have been lost, place, culture and tradition.

In order to show how hunger grows the poet uses the verb crawl. As a slow process that creates and forms an increasingly perceptible feeling, hunger crawls into the man's awareness. In the poet's viewpoint, the origin of hunger is something deep inside man, from out of his muscles. This hunger is a symbol for the natives' yearning for identity. Ortiz's poetry is inspired by his Native American heritage and develops a strong connection and a certain sense of identity with his past.

Hunger crawls into you

from somewhere out of your muscles 
or the concrete or the land

or the wind pushing you. (1-4)

At the beginning what the hunger asks seems minor but time by time the demands become higher. For example at the beginning, hunger asks for memory of human contact but after some time, it begins to ask for human contact itself, and not just any contact but one in the poet's native homeland; it demands a return to native traditions and rituals and the world the poet knows. It means, the poet doesn't know New York City at all and there, he is only an outsider. The poem opens by describing hunger as a kind of an animal that can "crawl into you." It is shown as something that emerges from outside but in line 2 it turns out that it actually comes from somewhere "out of your muscles". Thus, this hunger is not spiritual; it emerges out of the tension in one's muscles. The final two lines of the stanza show that hunger can have more than one source through using "or." In other words, this hunger must come from somewhere before crawling into one out of their muscles. Once hunger has consumed one, it starts to ask things. Hunger, here, is personified as it has the ability to demand things.

It comes to you, asking

for food, words, wisdom, young memories

of places you ate at, drank cold spring water, or held somebody's hand,

or home of the gentle, slow dances,

the songs, the strong gods, the world

you know. (5-11)

Through igniting the poet's desire to go back home, hunger 'searches [him] out'. Little by little it processes the poet and starts asking more personal questions. At the beginning, the answers to these questions seem easy but after some time, they become more difficult. Finally hunger assumes full power and by asking difficult questions, reminds the poet of his responsibility towards his homeland

That is, hunger searches you out.

It always asks you,

How are you, son? Where are you?

Have you eaten well?

Have you done what you as a person

of our people is supposed to do? (11-16)

Consequently, the poet feels guilty for his attempt in answering the questions the hunger poses so he draws his attention away from his memories and his wish to go to his homeland and gets back to "the concrete of this city".

And the concrete of this city,

the oily wind, the blazing windows,

the shrieks of automation cannot,

truly cannot, answer for that hunger

although I have hungered,

truthfully and honestly, for them

to feed myself with. (17-23)

In the second stanza, the poem elucidates that besides demanding food, hunger asks for other needs such as "words, wisdom, young memories, of places you ate at, drank cold spring water, or held somebody's hand, or home of the gentle, slow dances, the songs, the strong gods, the world you know." These other things that hunger demands are mentioned correspondingly and interchangeably with food which is necessary for man's survival. Ortiz holds that hunger asks for his home in Acoma Pueblo, the very world he comes from. In this phrase, the poet asserts that he feels as a stranger in New York City and conveys his sense of unfamiliarity with the city and also discomfort to the reader. The unpleasant concrete and wind of New York City take the poet to a place in his memory in which he can find comfort, peace, familiarity and relationships

So I sang to myself quietly:

I am feeding myself

with the humble presence

of all around me;

I am feeding myself

with your soul, my mother earth;

make me cool and humble.

Bless me. (24-31)

Ortiz clarifies that hunger continues to catch man in order to remind him that it exists. In the poem, hunger asks some questions similar to the ones that a close member of family usually asks in a long distance phone call indicating that this 
hunger is not only a food hunger. "How are you, son? Where are you? Have you eaten well? Have you done what you as one of our people is supposed to do?" In fact, Ortiz has personified hunger in this poem in order to represent his profound desire for his homeland generated by his unpleasant life in the unfamiliar and cruel atmosphere of New York City. Ortiz's strong sense of identity along with his abundant sense of responsibility to his Indian culture is revealed in the last question.

The next stanza expresses the poet's view that what the city provides him with cannot really satisfy his hunger. He cannot be pleased in a violent place with polluted air, concrete, bright lights, and noise. He declares that he honestly did his best to adapt himself to the city life and to be satisfied with its atmosphere but he failed. The reader perceives the poet's sense of resentment toward the city through his dull descriptions of it and understands that the city cannot satisfy the poet's hunger.

The last stanza the author seems to pray in a quiet song with closed eyes assuming that even his present environments are still a part of "mother earth" despite their disagreeableness. The poet also asks mother earth to comfort him since he is satisfied with her blessing soul. As a cool and placid appeal for peace and comfort, he wants mother earth to make him calm and modest, and to bless him.

Ortiz's profound connection with his Native history and culture is revealed in his poem. It demonstrates that regardless of how far away he may be, he feels the hunger for his own people indicating one's past remains in them even if they go far away. He is proud of his rich culture and discovers his comfort there. In this poem, the concept of hunger signifies a type of homesickness that someone feels when they are away.

In the poem "Going toward Pojoaque, A December Full Moon/72," Harjo describes the moon's action which is instantly evaluated in relation to its mythic sphere (Ruppert, 1983). The moon is making silver/ snail tracks over frozen / white earth/ it is a winter ghost hunter/ for old bones in the snow/ the full moon was so bright / I could see the bones in my hands. (Harjo 1979,25) Searching for some truth and also the essences of beings on earth, the moon becomes a hunter who must pierce the snow to find the essence. The woman's implicit identification with the moon's action determines her personal understanding. The Moon helps her in the process of searching and she can see into her own essences, deep to the bone. The process of understanding the mythic space and reaching self-recognition is obviously seen through understanding mythic space and fusion with it (Ruppert, 1983, 36).

In her poems, Joy Harjo asserts this fact too. She first portrays the original loss of the Natives and their struggle to reclaim their expunged identity and then mentions that in order not to forget, one must keep telling the truth. She regards remembering as an animated factor which influences the future. For her, poems are originated from mingling imagery and pure memory. (Harjo 55). Harjo depicts this fusion in her poems when she remembers and expressed the lives of her ancestors as well as of the people who were not successful in their search for identity. She asserts that truth is demanded in poetry (Harjo 141). By truth she means representing the history in a most sincere way. Harjo represents the truth of the Natives through its illustration in her poems, a poetic discourse of testimony.

"New Orleans," is a poem representing a journey along the Mississippi to New Orleans. The poem portrays the complaints of the poet who is in search of her ancient and valuable treasure of history-as-memory. The poem focuses on the massacre of the Creek people and their deprivation of own lands by European colonizers and the U.S. government which resulted in the peoples' loss of identity and also the eradication of their native culture. Here, Harjo adopts the role of a speaker-traveler who holds presumptions of feeling the muted voices of the Natives who were slaughtered and buried under the mud of the Mississippi. The poem also represent the Native viewpoint in a humorous mode when visualizes an ornament seller devastated by magical red rocks which recompense the unwary for the crimes committed during the colonization of America by the European invaders. In search of an acquainted Indian face, the speaker shifts the shape skillfully and as a swimmer plunged into blood, a estuary in the skin.

The climax of this non-linear poem appears quite late in its 37th line; however, deftly exposes its aim: The myth of El Dorado exacerbated the death-dealing Spanish conquistador/colonizer Hernando De Soto. In a city with black slaves, where merchants sell showy but cheap and of poor quality "mammy dolls / holding white babies", the topic overlooks the white's wrongs to needle Latino De Soto, who practiced violence against the Creek. While in history, De Soto died of fever and was buried in the Mississippi river, telling another version of history, the poem swings from the lavishness of New Orleans to the Creek lands, claiming that the Indians drowned the violent death-dealer in the Mississippi. Similar to the graves of Louisiana that "rise up out of soft earth in the rain," De Soto's ghost accepts his fate and does a Bourbon Street death dance with "a woman as gold / as the river bottom."

In Harjo's viewpoint, the spirit of the Creek De Soto is still so strong that even centuries later one can feel it from the depth of the earth. As a result, the strength and richness of the Creek culture are the keys of its survival. In "New Orleans" the poet demonstrates her ability to re-create the history of her people in the vaster framework of the violence used to create America on Natives' account. In addition to depicting the Native's grief and heartbreak of the expatriation, the poem expresses the strength proven by their ability to survive which is called a "beautiful survival." Harjo is very positive about the possibility of regaining what is lost. She says, "the focus on what is being "lost" reinforces what we are told about ourselves, that we are dying, that our cultures are dying. Yet all around me I see evidence of the opposite." (Bird \& Harjo, 1997,25 ) 


\section{Conclusion}

Since colonialism is a denial of a nation's cultural history and values, what that nation is to do as a means of resistance is to reassert its history and culture and try to reclaim it. The challenge was made even more difficult as their history and even sense of identity was assimilated into the Whites' history and identity; this, nevertheless, did not stop the native Americans, especially their thinkers, writers, and poets, from reclaiming what was theirs even if it meant using the Whites' language against themselves; this is what each one of the Native American poets discussed in this paper tried to do achieving different degrees of success. This shows greatly in the art they produced and since art cannot exist apart from reality, the influence was carried over to the natives' lives as well. One could say that Native American rtists planted the seeds of resistance that later on bloomed to affect the whole cultural front of their people.

Ortiz describes several changes which took place after Native American people's expatriation from their own homeland as geographic dislocation. As a result of colonialization and assimilation the natives were disturbed between past and present. Harjo reflects her great sorrow with the colonizer who according to her steals her people land while forcing them to talk in English (the colonizer language).

\section{References}

Barnes, Joshue. Having to fight for it: An interview with poet/ Musician Joy Harjo. November 15, 2013, accessed March 8, 2014, http:// www.samponiaway.org/literary-voices/2013/11/15.

Barry, Peter. Beginning theory: An introduction to literary and cultural theory. Manchester university press, 2002.

Bird, Gloria, and Joy Harjo, eds. Reinventing the enemy's language: Contemporary Native women's writing of North America. WW Norton, 1997.

Carpenter, Ron. “ Zitkala- Sa and Bicultural subjectivity.” Studies in American Indian literatures 16 (2004): 1-28. ProQuest.

Cruz, Yaneirys. Ortiz's poetic sequence challenges. 2013.

Fast, Rbin Riley. “ “It is ours to know: Simon J. Ortiz's from Sand Greek.” Studies in American Indian Literature. 12.3. 2000: 52-63 print.

Ruppert, Jim. "Paula Gunn Allen and Joy Harjo: Closing the Distance between Personal and Mythic Space." American Indian Quarterly (1983): 27-40.

Mcleod, John. Beginning postcolonialism. Manchester university

Powell, Malea ed. Studies in American Indian literature. University of Nebraska. 2006.

Tapahonso, Luci. Blue horses rush in: poems and stories. Vol. 34. University of Arizona Press, 1997.

Zhaogue, D. I.N.G. “On Resistance in Anti-colonial Marxist writings.” Candian Social Science 7.1 (2011): 38-48 “The poetic of Carol Muske and Joy Harjo.” 123Help Me.com.09Jul 2014. 